Luís Augusto Barbosa Cortez; Carlos Eduardo Vaz Rossell; Rodrigo Aparecido Jordan; Manoel Regis Lima Verde Leal; Electo Eduardo Silva Lora. "R\&D NEEDS IN THE INDUSTRIAL PRODUCTION OF VINASSE", p.619-636. In Luis Augusto Barbosa Cortez (Coord.). Sugarcane bioethanol - R\&D for Productivity and Sustainability, São Paulo: Editora Edgard Blücher, 2014.

http://dx.doi.org/10.5151/BlucherOA-Sugarcane-SUGARCANEBIOETHANOL_55

\title{
R\&D NEEDS IN THE INDUSTRIAL PRODUCTION OF VINASSE
}

\author{
Luís Augusto Barbosa Cortez, Carlos Eduardo Vaz Rossell, \\ Rodrigo Aparecido Jordan, Manoel Regis Lima Verde Leal \\ and Electo Eduardo Silva Lora
}

\section{INTRODUCTION}

This chapter investigates aspects related to the need for new research on vinasse, with the aim at the improvement of techniques, or implementation of new processes, which allow a reduction in the volume of this byproduct and/or its pollution potential. Sugarcane vinasse is an agri-industrial residue generated in high volumes with a high pollution potential.

The low tolerance to alcohol by the yeast $S a$ charomyces Cerevisiae, used in alcoholic fermentation, implicates a high dilution rate of the must so that the alcohol by volume of the wine is not high after distillation, in the generation of vinasse per liter of ethanol (about 7 to 14 times). Higher temperatures in the fermentation process reduce even more the tolerance of yeast to ethanol.

The technical solution found in Brazil for the disposal of this byproduct is fertirrigation, already discussed in this book. However, since there are restrictions and laws in other countries prohibit this practice, it is very important to find a reduction to the volume and even in situ elimination of vinasse.

There are already some options to reduce the volume of vinasse produced. For example, genetic improvement to increase resistance of yeast used in fermentation, changes in the process, such as use of vacuum, or membranes for continuous extraction of the alcohol produced or employment of refrigeration for temperature reduction and control during fermentation; which would permit an increase in the alcohol by volume of the wine. Another possibility is to concentrate the vinasse, either by evaporation or through reverse osmosis. All of these technologies are currently in different stages, needing further development and research.

In terms of reducing pollution, bio-digestion appears as a good alternative for vinasse treatment, at the same time that offers the possibility of generating energy from the biogas produced. However, bio-digestion does not solve the problem of high volume of vinasse generated.

There are still two main questions still need answers. The first concerns the optimum quantity which could be generated (volume vinasse/volume thanol produced). The second question involves the vinasse of second generation ethanol, of what could be their characteristics, that is, the volume and its treatment.

\section{SUGARCANE VINASSE}

In Brazil, the largest part of the vinasse produced comes from the fermentation of the juice mixed in different proportions to the molasses obtained in centrifuging sugar, given that currently, the majority of units produce both sugar and ethanol. Figure 1 shows a flowchart with the phases in sugar and ethanol production, and where vinasse is generated.

The quantity of vinasse generated in the production of alcohol is associated to the toxicity of ethanol to the yeasts used, indicating a reduction in the alcohol by volume during the final stage of 


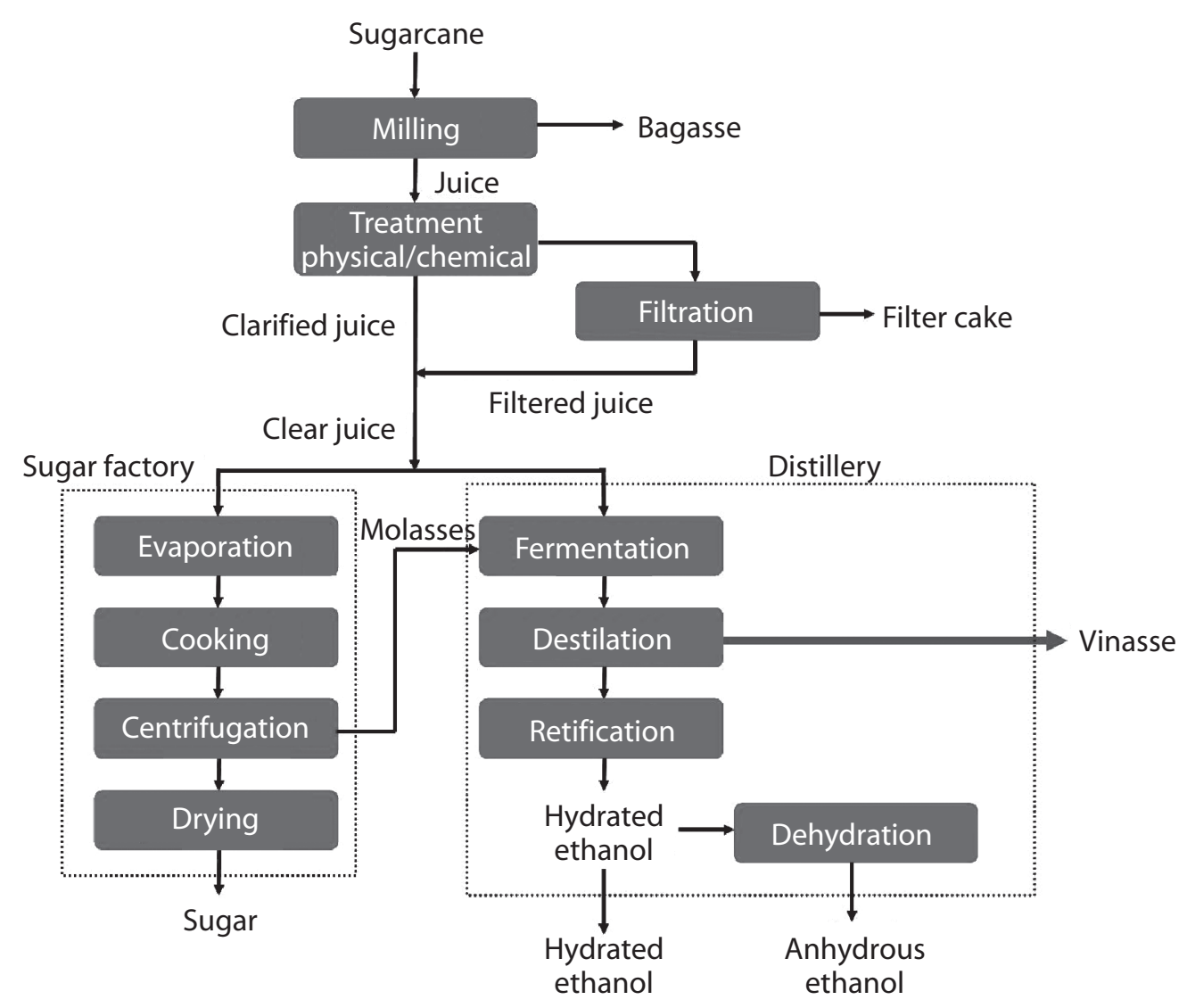

FIGURE 1 Sugar and ethanol production flowchart.

the fermentation process, including recycling of the yeast during the harvest. This causes, for the same recipient volume, a reduction in the volume of alcohol produced and an increase in the quantity of vinasse generated. With the final average alcohol by volume obtained today in the mills of about 8 to $12{ }^{\circ} \mathrm{GL}^{1}$, there is, for every liter of ethanol produced, between 7 to 14 liters of vinasse.

Generally the vinasse is of a light brown color with $2 \%$ to $4 \%$ total volume of solids when it is obtained from sugarcane, and presents a slightly reddish dark color (black) with a volume of solids

\footnotetext{
1 In average the mills with attached distilleries operate with an alcohol by volume of approximately $8.5^{\circ} \mathrm{GL}$. This may be gradually higher however smaller the percentage of molasses incorporated. The mills which due to good cooling conditions, operate with an elevated ratio sugarcane to ethanol: sugarcane to sugar and have good installations and process management reach maximum levels of 10 to $10.5^{\circ} \mathrm{GL}$ in stable levels.
}

between $5 \%$ and $10 \%$ when produced from sugarcane molasses.

The organic substances present in vinasse generally increase the Biochemical Oxygen Demand (BOD), generally between 30,000 and 40,000 mg/l (BHANDARI et al., 1979) with a $\mathrm{pH}$ of 4-5. The organic acids present in vinasse are corrosive requiring stainless steel or fiberglass, or coated recipients which come in contact with the vinasse. The vinasse also contains non-fermented carbohydrates, dead yeast, as well as a variety of inorganic compounds all of which contribute to a high BOD.

When vinasse cannot be applied in fertirrigation, some distilleries employ the so-called "sacrifice $\operatorname{areas}^{2}$ ". However, depending on the location, these areas are a great risk to the water tables and rivers due to the risk of lixiviation.

\footnotetext{
2 The vinasse volume applied to sacrifice areas is estimated in no more than $20 \%$ of the total generated.
} 
Due to the fact it is a highly pollutant residue, about one hundred times more than domestic sewage, which also comes out of the process at a relatively high temperature, around $85{ }^{\circ} \mathrm{C}$ to $90{ }^{\circ} \mathrm{C}$ (GONÇALVES, 2008), finding an adequate destination is one of the great challenges of the sector.

It was after the NATIONAL ALCOHOL PROGRAM (1975) that the fertirrigation technology took off in Brazil, as a disposal method for vinasse. Although it was in fact a good alternative it has economic limitations due to high transport costs when transported long distances and also due to restrictions imposed by law on the total amount that can be applied to the saoil (see Chapter 9, Part 3, Fertilizers for sugarcane). These restrictions forced the sector to find other alternatives close to distilleries or mills.

\section{R\&D NEEDS TO REDUCE THE VOLUME OF VINASSE}

All of these aspects demand more research with the objective of finding solutions to ease the environmental and economical impacts caused by large volumes of vinasse. Some advances were achieved, such as the cooling of the fermentation towers using fresh water from rivers, which allowed some mills to reduce the fermentation temperature to values less than $34^{\circ} \mathrm{C}$, resulting in fermentation period of about 6 to $8 \mathrm{~h}$, considered acceptable when compared to 24 hours about 30 years ago.

However, the volume of vinasse produced is still very high, making transportation costly. Vinasse is composed almost entirely of water, as the solids level is very low ( $5 \%$ to $10 \%$ ) due to high dilution.

Alternative uses of vinasse, to reduce the high BOD, bio-digestion to generate energy which can at the same time help to reduce the pollution potential (reducing the BOD and the volume produced, through greater vinasse concentration. Vinasse concentration is a process which may be done by reverse osmosis and/or evaporators. However the latter requires high quantities of thermal energy.
A way of reducing vinasse generation according to FINGUERUT (n.d.) quoted by PENATTI (2007) is to increase the final alcohol concentration by volume of the fermentation. Each percentage increase in the alcohol by volume corresponds to a percentage reduction in the number of liters of vinasse per liter of alcohol produced.

There are already many lines of research e.g. reduction in fermentation temperature through refrigeration systems in the recipients, increasing alcohol by volume of the wine and consequently reduce the volume of vinasse. On the other hand, the temperature reduction to less than $28{ }^{\circ} \mathrm{C}$ implies a reduction in the metabolism of the yeast, increasing the fermentation time; or the use of a vacuum process for the continuous extraction of ethanol during fermentation. These techniques, however, are still restricted to laboratory prototypes; additional where investment is necessary to scale-up. It has been also proposed, to reduce the volume of vinasse reduction, to recycle in the process, to ferment the diluting must to be e.g. process known as Biostil.

Alternatives which involved an increase in alcohol by volume in fermentation, as well as reducing the vinasse, show other advantages, an increase in the production of the alcohol in the recipient and a reduction in energy consumption in distillation due to greater concentration of alcohol in the wine.

AMORIM (2008) mentions the improvement in contamination control in fermentation as another benefit of working with higher final alcohol by volume in fermentation. Table 1, quoted from AMORIM (2008) shows the relation between the final concentration of alcohol in the wine and the quantity of vinasse generated per liter of distilled alcohol. However, data on fermentation, type or even time is not contemplated.

According to FINGUERUT (n.d.) quoted by PENATTI (2007), except from some few mills which manage to work with higher alcohol levels, most work with alcohol by volume levels between $8 \%$ and $8.5 \%$. Some alternatives aimed to reduce or treat vinasse, are described below in more detail. 
TABLE 1 Vinasse volume generated due to alcohol by volume in wine.

\begin{tabular}{|c|c|}
\hline $\begin{array}{c}\text { Alcohol by volume in wine } \\
\text { (\%) }\end{array}$ & $\begin{array}{c}\text { Vinasse volume } \\
\text { (liter/liter of alcohol) }\end{array}$ \\
\hline 5 & 20 \\
\hline 7.5 & 13 \\
\hline 10 & 10 \\
\hline 14 & 7 \\
\hline 18 & 5.5 \\
\hline
\end{tabular}

Source: AMORIM (2008).

\section{ALTERNATIVES FOR VINASSE VOLUME REDUCTION IN FERMENTATION}

\section{Biostil Process}

The Biostil process (Figure 2) was developed with the aim of reducing the volume of vinasse by increasing the concentration of solids, which normally is of $5 \%$ to $15 \%$, through recycling in the fermentation process, which consists in using it in the dilution of the honey in a substitution of water.

To obtain vinasse at $14.5 \%$ solids, NILSSON (1981) recommends its recycling in fermentation but which requires a substrate of higher quality, as well as other microbiological attention. The Biostil process, patented by the company Alfa Laval, was commercialized in Brazil by Dedini.

The first tests were set up for a small plant of 18,000 liters of ethanol/day, and later at Usina São Luiz, a commercial plant of 180,000 liters of ethanol/day. Dedini sold 4 units in Brazil as well as 1 in Pakistan. None of theses plants are currently in operation.

The Biostil process was developed in the 1980s, whose main objectives were operation with concentration musts and the reduction of vinasse volume. However, this process showed serious problems which hinderer its commercial viability. For example, the must was highly toxic due to vinasse recycling to dilute the concentrated molasses. Additionally, the must showed high osmotic pressure due to the presence of non-fermentable

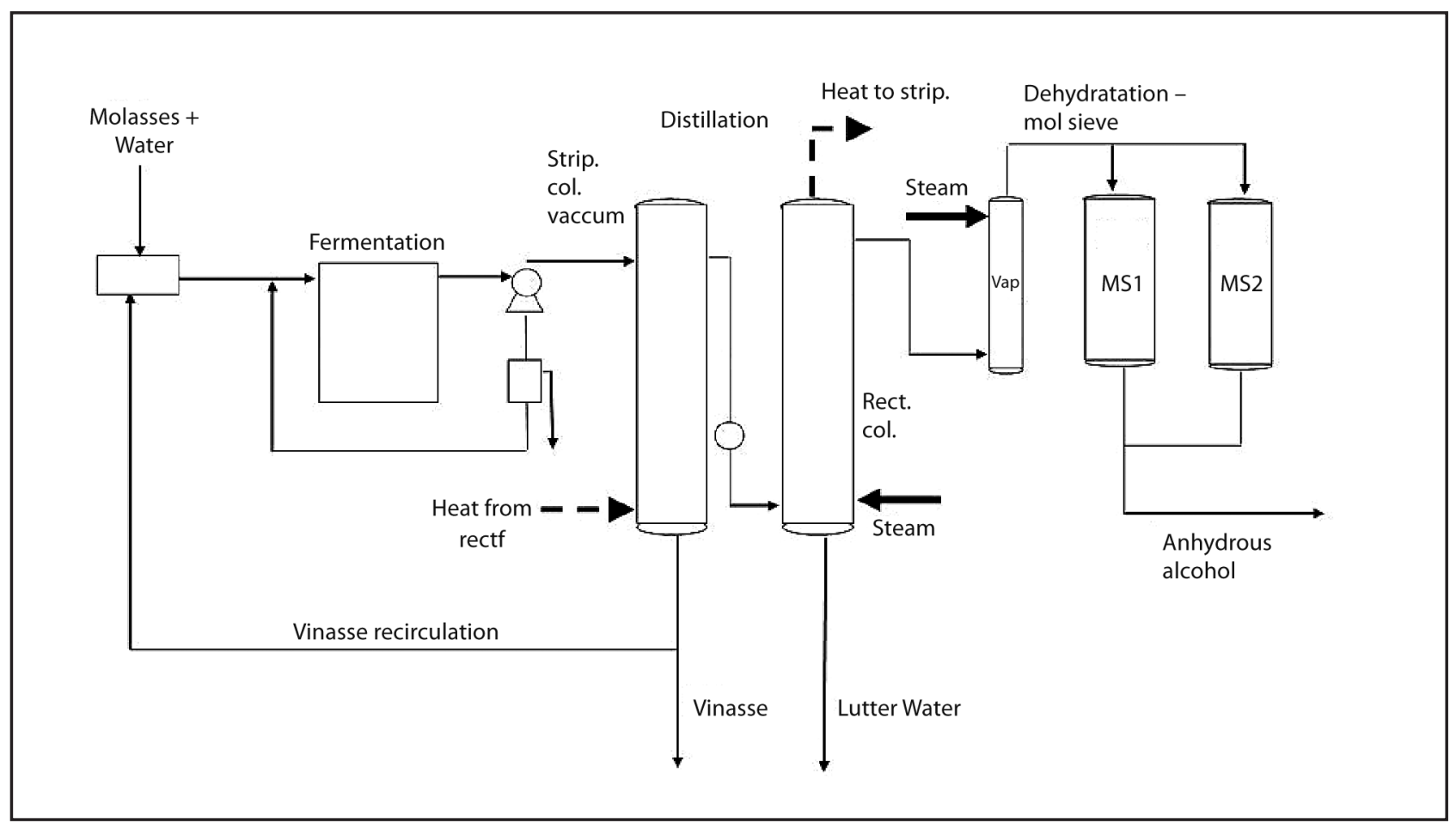

Source: BIOSTIL, (1983) adapted.

FIGURE 2 DEDINI fermentation process with vinasse recirculation. 
soluble solids in relatively high concentrations. These two factors resulted in a low productivity process (ATALA, 2004).

According to Dr. Olivério of Dedini (personal communication), when the Biostil process was introduced at the beginning of the 1980s, little was still not known how to treat vinasse. The use of vinasse in fermentation reduced the yeast life cycle. It is important to recall that the raw material used was molasses and that vinasse was still diluted for fertirrigation many times. It made, therefore, no sense to concentrate the vinasse only to dilute it later.

According to FINGUERUT (n.d.) quoted by PENATTI (2007) the Biostil process was not commercially demonstrated in Brazil, as it simply did not work as it would work in India in low efficiency and low productivity conditions, reducing its attraction for reducing the vinasse volume. A possible advantage of the Biostil process was that it was easier to evaporate the juice (to make a syrup which would be diluted with the vinasse) than to evaporate the vinasse, which due to its corrosiveness, would demand special materials for evaporation, increasing the cost.

Procknor Engenharia describes in its website (<www.procknor.com.br $>$ ) the development of projects of ethanol production plants in other countries, where the Biostil system has been applied successfully for reducing the volume of vinasse. For this, a specific yeast is used which can take high osmotic pressure. Fermentation is continuous, and yeasts are recovered by means of separating centrifuges, with no acid treatment. Dilution of the honey is made by the recycling vinasse itself. Although it is a special yeast, the fermentation environment is so hostile for its metabolism that after about one week of operation the yeast must be renovated. In this way, there would be two fermenting agents, one in operation and the other for the propagation of the new addition of yeast. When the fermentation level starts to decline, the yeast is changed using the fermenting agent on hold and so on.

According to Procknor, recycled vinasse has a Brix of around $35 \%$ and its rate is of about $3: 1\left(3 \mathrm{~m}^{3}\right.$ of vinasse $/ \mathrm{m}^{3}$ of alcohol). According to information from this company, in Australia there is a system in operation with a productivity of about 3 percentage points below the productivity of the classic Melle Boinot process. As well as a reduction in viability of the yeast due to the fermentation conditions, there is the constant consumption of sugar used in the propagation of new yeast additions.

In Sarina, Australia, a distillery operating since 1989 with the Biostil process, produces 180,000 liters of ethanol/day; the vinasse with $30^{\circ}$ Brix is sold as liquid fertilizer to farmers in the region. In the recent past, the company Chematur Engineering took on Biostil technology and has been working to improve it, solving its serious chronic problems; according to Chematur there are about 30 distilleries in India operating with their technology. The yeast used is Schizosaccaromyces pombe. More information on the Biostil 2000 technology may be obtained in the Chematur company's website (<www.chematur.se $>$ ). The company PRAJ applies this process in the new distilleries built in Colombia. One of the problems faced are the infections in the fermentation musts.

\section{Use of Refrigeration for Temperature Reduction in Fermentation}

Temperature reduction in the fermentation process appears as an alternative both for vinasse reduction as for an increase in the volume of alcohol produced. Temperature is as a very important factor in the fermentation step, as increasing it implicates lower tolerance of the yeast to the ethanol's toxicity. On the other hand, reduction increases the yeast tolerance, allowing for work with higher alcohol concentration in the wine.

The recipient cooling tower technique with fresh water from rivers, in the past, when harvest was concentrated in colder months, allowed for significant improvements in the process, such as reduction in the fermentation period and production gains related to the recipient temperature reduction (AMORIM, 2005). Nowadays, as sugarcane season extends to warmer months, this cooling system has proved to be inefficient. The problem is even greater in mills installed in the warmer regions, where it is difficult to work with 
temperatures below $35^{\circ} \mathrm{C}$, which is according to technical literature, the top temperature limit, after which the yeast becomes more susceptible to the alcohol by volume.

With the aim of improving the cooling systems in the fermentation recipients, some mills are using cooling towers. This does not solve the problem, as these towers operate on the evaporation principle, where part of the water evaporates through forced air passage through the water current, thus promoting heat removal. However, for the process to work efficiently, the relative air humidity must be low. Contrary, evaporation is hindered, affecting heat exchange and efficiency of the process.

There are many bibliographical references on temperature in the fermentation process, among which we may quote: FINGUERUT et al. (2008), GUTIERRES (1993), JONES et al. (1981) and WALKER and CAPRIOLO et al. (1985) quoted by OLIVA NETO (2008), Parazzi (2008) and Amorim (2008). There seems to be a consensus as to the benefit of temperature reduction in the process. However, the economic viability of employing refrigeration for temperature reduction has always been matter of debate.

According to AMORIM (2008), the challenge of alcohol by volume levels greater than $11 \%$ is related also to the need for improving the cooling system, thus suggesting refrigeration systems.

According to FINGUERUT et al. (2008) one of the initial limitations for the increase in final alcohol by volume in fermentation is the resistance of the yeast population to the toxic effect of the ethanol produced, considering the need to reuse the yeast. It is possible to reduce this effect by reducing the process temperature and then working with a younger population of yeast. Considering that adopting such measures implicates greater investment,requires to balance possible costs with gains in capacity; higher electricity generation and reduction in the volume of byproducts must be also emphasized.

In the past, due mostly related to production costs, the idea of using refrigeration systems to reduce the temperature in the recipients and thus improve fermentation was eventually abandoned, due largely to high energy costs.
There is still a strong need to carry out basic research e.g. behavior of yeast in low fermentation temperatures $\left(10{ }^{\circ} \mathrm{C}\right.$ to $\left.25^{\circ} \mathrm{C}\right)$. In many research studies involving temperature, it may be seen that the values were restricted to a small range, between $28^{\circ} \mathrm{C}$ and $40{ }^{\circ} \mathrm{C}$. Yeast development however happens in a broader range of temperature.

According to JONES et al. (1981) quoted by OLIVA NETO (2008), the Saccharomyces Gerevisiae yeast tolerates up to $33{ }^{\circ} \mathrm{C}$ in industrial conditions for the production of ethanol, in spite of showing a growth rate between $10^{\circ} \mathrm{C}$ and $40^{\circ} \mathrm{C}$. JIMENEZ and VAN UDEN (1985) quoted by ANDRADE (2007), the tolerance range to ethanol is in between $12{ }^{\circ} \mathrm{C}$ and $28{ }^{\circ} \mathrm{C}$, decreasing at values greater than $28^{\circ} \mathrm{C}$. Above $35^{\circ} \mathrm{C}$ the yeast becomes little tolerant to ethanol, occurring a reduction in the cellular and ethanol production (PHISALAPHONG et al. 2005, quoted by ANDRADE, 2007).

A complete project should consider laboratory studies of the initial phase and the scale-up of the proposed system. Once determined the optimum condition, it must be applied to a larger system, as there are factors which are affected by scale.

Using refrigeration for temperature control in a mill, considering the fact the recipients are already cooled down with water, would imply changes that are not necessarily significant to the process. In a simpler case, adopting refrigeration in a fermentation process, would sum-up to the installation of a cold water accumulating tank connected to a refrigeration system to cool the water.

The company Thermax of Brazil, in association with Procknor, is offering a system for cooling the recipients. It is an absorption chiller which produces cold water between $15{ }^{\circ} \mathrm{C}$ and $22{ }^{\circ} \mathrm{C}$. According to information from the company the absorption system may use, to be activated, many heat sources available at the mill, such as vinasse, condensates or vapor at temperatures below $100{ }^{\circ} \mathrm{C}$. This system is recommended for maintaining the recipient temperatures around $33^{\circ} \mathrm{C}$. There are no published economic data or results of any installation already in operation.

Dedini has an agreement with Thermax, having built a demonstration plant at the Usina Bonfim. There is a consensus nowadays as to the need 
to control fermentation temperature and the use of refrigeration systems by absorption; seems like an interesting solution from a technical point of view (as it uses low pressure vapor as basic energy source) and economically (as this vapor may be obtained at a relatively low cost in the mill).

\section{Fermentation System with Continuous Extraction through Vacuum}

In the last few years, many researchers have proposed the use of techniques to extract ethanol from the wine as it is produced to improve the performance of the fermentation process. Using vacuum during the fermentation is one of the proposed methods.

Francisco Maugeri through the Bio-processes Engineering Laboratory of the School of Food Engineering at Unicamp has been working on the development of continuous extraction systems during fermentation. ATALA (2004) set up in laboratory, a continuous fermentation process, with vacuum extraction through a flash type evaporator. One of the greatest challenges was developing the control method for the process. According to this author, the results obtained were excellent, showing that it is possible to work the extraction with a solution of alcohol by volume of around $50^{\circ} \mathrm{GL}$, maintaining in fermentation a low concentration of ethanol, of about $5 \%$ ( $\mathrm{vol} / \mathrm{vol})$, not very inhibiting to the yeast.

According to ATALA (2004) the flash type evaporator used in his work permits fermentation with high concentration of sugars in the reactor feeding medium, resulting in a greater production of ethanol, which would imply in cost reduction for distillery and smaller vinasse generation. On the other hand, there is additional energy consumption through the flash evaporator vacuum system.

However, the necessity of carrying out tests with this process on a larger scale must still be considered, since the system set up in laboratory used a fermenting system of a few liters. In addition, the energy consumption by most of the equipments necessary must also be considered, which was not the main purpose of the first study, which sought to demonstrate only the validity of the process.

\section{VINASSE TREATMENT METHODS}

\section{Vinasse Bio-digestion}

Given the high COD characteristics of vinasse, low level of solids and production in large quantities from a central point of the distillery, treatment via anaerobic digestion was considered, which is a method used quite successfully in the treatment of liquid byproducts with low level of solids. Many examples of application of bio-digestion can be found in the Brazilian food industry, particularly in the beer sector.

The advantages of the anaerobic bio-digestion process, LUCAS JR. et al. (1997) are:

- lower energy consumption in relation to the traditional aerobic treatment processes;

- lower production of muck (bacteria) in relation to the aerobic processes;

- acceptance of higher levels of organic matter;

- the methane produced may be used as fuel;

- the byproduct of vinasse treatment may still be used as a fertilizer, given that all the nutrients present in the "fresh" vinasse are also present in the byproduct.

Development of the Upflow Anaerobic Sludge Blanket Reactor, known as the UASB reactor (schematic view in Figure 3), allows treatment of the liquid byproducts with an elevated COD, as is the case of vinasse.

The UASB bio-digesters are currently used with greater success in anaerobic bio-digestion of vinasse and other liquid byproducts, as was previously mentioned. This is due to the fact that fresh vinasse has a low level of solids, which allows pumping and recirculation and therefore, obtaining a rather low residence time of only a few hours, contrary to that found in conventional bio-digester, Indian or Chinese type, which are not adequate for this purpose.

The operation principle of the UASB biodigester is based on the recirculation from bottom to top of vinasse through a fixed blanket of microorganisms located in the middle of the reactor. The UASB reactor is characterized for having a separated superior section for the liquid phases and gases, which allows part of the liquid 


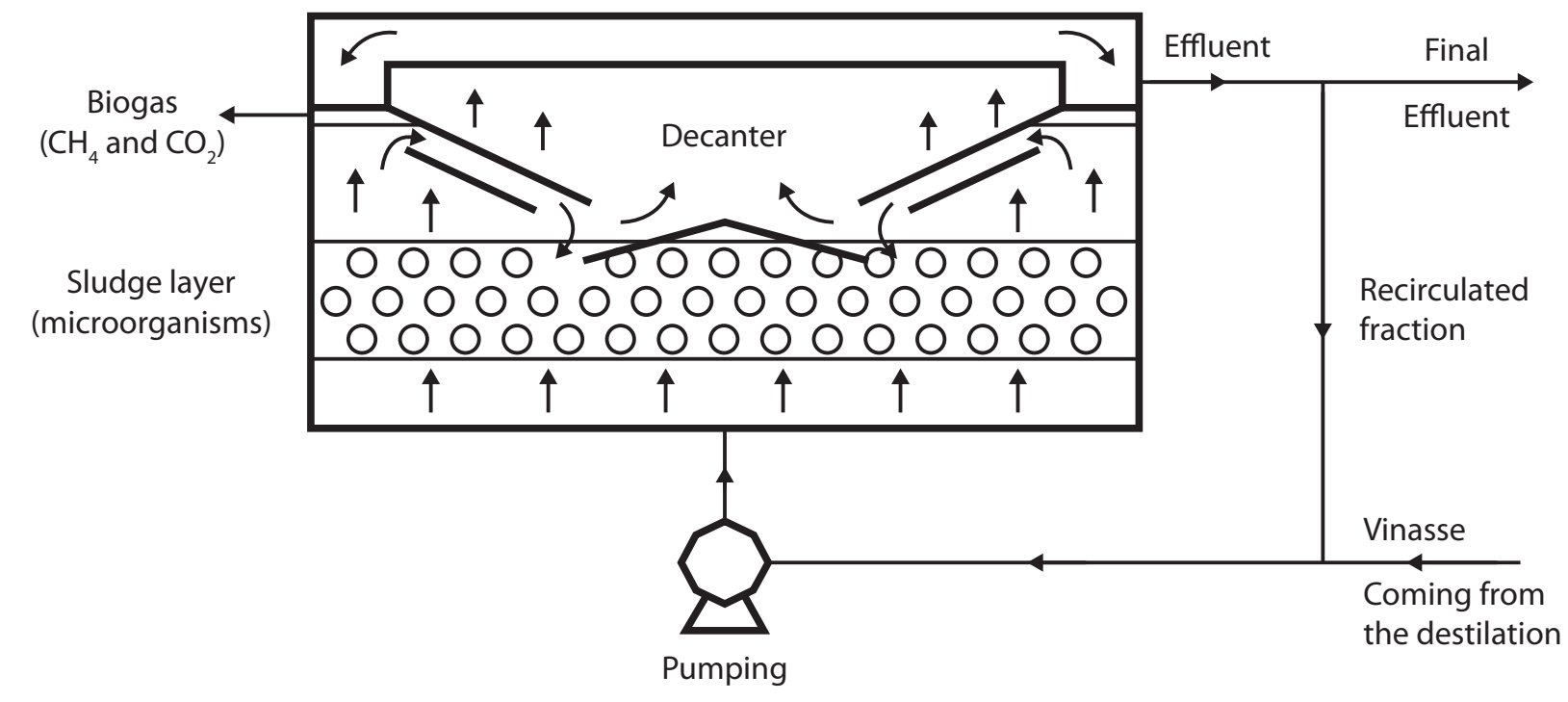

FIGURE 3 Adapted schematic sketch of a UASB reactor.

to return while it maintains the bacteria fixed in the reactor's bed.

The vinasse is, therefore, pumped externally and introduced into the lower part of the reactor passing by the muck blanket where there are the microorganisms responsible for the conversion of the organic matter present in vinasse into $\mathrm{CH}_{4}$ and $\mathrm{CO}_{2}$. The resulting liquid byproduct comes out of the superior side part of the reactor, while the gaseous part $\left(\mathrm{CH}_{4}\right.$ and $\left.\mathrm{CO}_{2}\right)$ is confined with the help of deflectors which takes it to spaces, also located on the superior part of the reactor. These reactors are normally cylindrical.

According to PINTO (1999), in Brazil the first experience with anaerobic digestion of vinasse didn't use UASB reactors, but a modified Indian type model. In 1981 a $330 \mathrm{~m}^{3}$ bio-digester was implemented at Destilaria Central Jacques Richer, in Campos, in the state of Rio de Janeiro. The bio-digester operated until the distillery closed in 1982 , obtaining a reduction of COD by $62 \%$ with the production of 16.5 liters of biogas (with $55 \%$ $\mathrm{CH}_{4}$ ) per liter of vinasse. The biogas was burned in a boiler without any modification in the burners projected originally for fuel oil.

Some initiatives conducted by the Institute of Technological Research of the State of São Paulo
- IPT, at the beginning of the 1980s, allowed for a considerable gain in experience in the application of bio-digestion technology for treatment of vinasse by using ascending flow bio-digester technology, such as the bio-digestion project at Destilaria Paisa in the state of Alagoas. This project was coordinated by the Brazilian Development Bank - BNDES and aimed to control the vinasse bio-digestion technology. The laboratory reactors were financed by many governmental agencies and by the company Tigrefibra Industrial S.A. Table 2 indicates, in more detail, some results as to the composition of the vinasse treated and the byproduct resulting from anaerobic bio-digestion in this project.

Also around the 1980s, the group CODISTILDEDINI acquired a Dutch technology for largesized UASB reactors, to operate with mesophylic bacteria, the METHAX-BIOPAQ process. The first large-sized unit was installed in 1986 at Destilaria São João, in the city of São João da Boa Vista, SP. The project was partially financed by the BNDES. The basic idea was to develop the vinasse biodigestion technology, which could, without much difficulty, be adopted by other distilleries.

The bio-digestion project of Destilaria São João operated for 13 years. The reactor had a 
TABLE 2 Average composition of vinasse and byproduct referring to the ascending flow bio-digester for vinasse project at Destilaria Paisa in Alagoas.

\begin{tabular}{|l|c|c|}
\hline \multirow{2}{*}{ Components } & \multicolumn{2}{c|}{ Average composition } \\
\cline { 2 - 3 } & Vinasse & Byproducts \\
\hline $\mathrm{pH}$ & 3.73 & 7.3 \\
\hline Total solids (g/l) & 25.2 & 10.9 \\
\hline Volatile solids (g/l) & 19.3 & 5.2 \\
\hline COD (mg/l) & 31,350 & 6,144 \\
\hline BOD (mg/l) & 17,070 & 918 \\
\hline Nitrogen (mg/l) & 412 & 343 \\
\hline Phosphorus (mg/l) & 109 & 108 \\
\hline Sulfate (mg/l) & 897 & $*$ \\
\hline Potassium (mg/l) & 1,473 & 1,221 \\
\hline \multicolumn{3}{|c|}{ COD reduction } \\
\hline Total & $80.5 \%$ & $94.6 \%$ \\
\hline Exceeding & $91.4 \%$ & $95.1 \%$ \\
\hline
\end{tabular}

Note: For a period of hydraulic retention $=1.5$ day, maximum organic load $=$ $18.7 \mathrm{~kg} \mathrm{COD} / \mathrm{m}^{3}$.day; biogas average production $=13.1 \mathrm{I} / \mathrm{l}$ of vinasse; conversion $=0.4 \mathrm{I} \mathrm{biogas} / \mathrm{g} \mathrm{COD}_{\text {adic. }}$; methane level $=60$ to $65 \%$;

* Not indicated in the reference.

Source: CRAVEIRO, 1986.

capacity of $1,500 \mathrm{~m}^{3}$ and the gasholder a capacity of $600 \mathrm{Nm}^{3}$ of biogas (Figure 4). The biogas generated was 70\% methane and 30\% carbon dioxide with traces of impurities. The biogas was then purified and compressed to 220 atm (22 $\mathrm{MPa}$ ) in reservoirs with total capacity of $400 \mathrm{Nm}^{3}$. The daily production of biogas reached $6,500 \mathrm{Nm}^{3}$ (96\% methane). The compressed $\mathrm{CH}_{4}$ was used to move 41 vehicles (29 trucks and 12 utilitarian vehicles), representing $50 \%$ of the fleet of trucks at the distillery and $40 \%$ of the utilitarian vehicles.

In spite of the fact the project at Destilaria São João shwed technical viability, economic factors prompted biogas as a vehicular fuel to be discontinued in the 1997/1998 harvest; it was used only in drying yeasts, as in Usina São Martinho. The vinasse bio-digestion unit at Destilaria São João has been deactivated which according to Dedini, contributing factors included:
- low price of diesel oil, which was high subsidized internally ( costing at the time half the price of gasoline); currently it is about 10\% cheaper);

- sugarcane logistics evolved to large quantities. At the time, the power of the truck engines was of $180 \mathrm{HP}$ (bus engines moved by gas were used) and today $400 \mathrm{HP}$ engines are needed and there aren't such engines moved by gas;

- in addition, there was also the difficulty in obtaining extra parts for the modified diesel engines used in fleet of trucks.

Since 1987, Usina São Martinho has developed a thermophilic process $\left(55^{\circ} \mathrm{C}\right)$ for vinasse biodigestion using a UASB type pilot reactor with $75 \mathrm{~m}^{3}$ capacity (Figure 5). After 5 years, the technology was considered fully developed. The thermophilic reactor was operated with an organic load applied at a rate of $30 \mathrm{~kg} \mathrm{COD} / \mathrm{m}^{3} /$ day producing $10 \mathrm{Nm}^{3}$ of biogas $/ \mathrm{m}^{3}$.day, under stable operating conditions. These values are considered twice as great as that presented in the literature on the mesophilic process $\left(35^{\circ} \mathrm{C}\right)$.

The most notorious cases of vinasse treatment with bio-digestion are Destilaria São João, which in the mid 1990s discontinued its operations, and that of Usina São Martinho, both in the state of São Paulo. Usina São Martinho is the only one still using bio-digestion. Both systems, despite producing good results from an energy point of view, remain economically very expensive.

Studies carried out by JOHANSSON et al. (1993) and quoted by SOUZA e PAULA JR. (1999), estimate the operational costs of biogas of biogas produced between 0.03 to $0.05 \mathrm{US} \$ / \mathrm{Nm}^{3}$, where for large-sized plants these costs would be lowered to $0.02 \mathrm{US} \$ / \mathrm{Nm}^{3}$. Considering also investment costs, for an installation with working life of 15 years and an interest rate of $10 \%$ p.a., the total costs would be of 0.05 to $0.09 \mathrm{US} \$ / \mathrm{Nm}^{3}$. Still in accordance to SOUZA e PAULA JR. (1999), when comparing these costs with that energy in terms of US\$/toe ${ }^{3}$ (1995 figures), the costs of biogas vary between

3 Toe $=$ ton of oil equivalent 


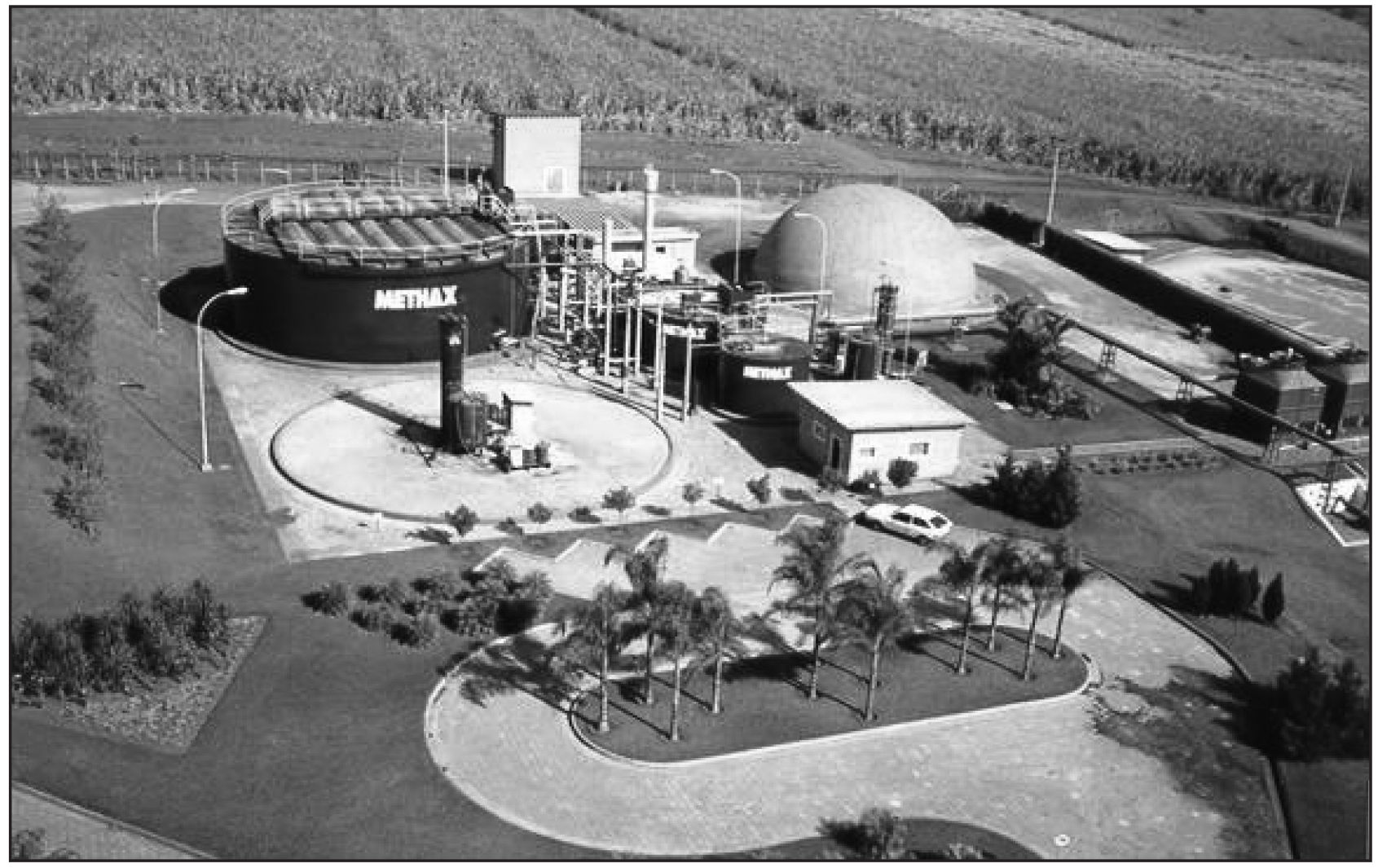

Source: Granted by DEDINI.

FIGURE 4 Picture of the Usina São João project showing the bio-digester and the gasholder.

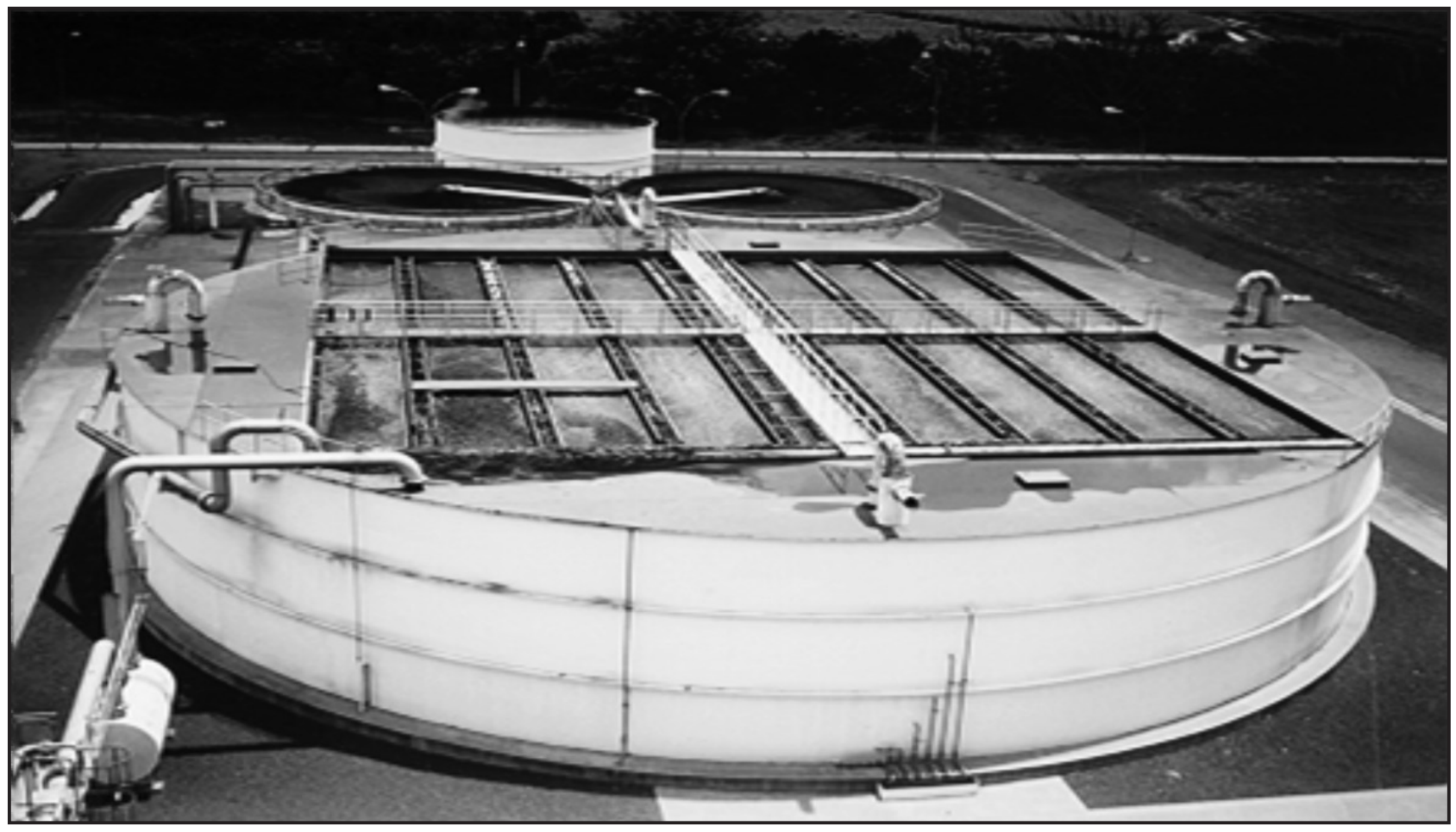

Source: PINTO (1999).

FIGURE 5 View of the bio-digester installed at Usina São Martinho. 
TABLE 3 Parameter comparison between the vinasse bio-digestion reactor projects, UASB and IC concepts.

\begin{tabular}{|l|c|c|}
\hline \multicolumn{1}{|c|}{ Parameters } & UASB & IC \\
\hline \multicolumn{1}{|c|}{ Anaerobic muck } & Active, concentrated & G stages \\
\hline S/L/G Separator & High biomass retention & $16-30$ \\
\hline Height of reactor (m) & $4.5-6.5$ & $20-40$ \\
\hline Muck activity (kg COD/kg SSV. d) & 0.5 & $2-3$ \\
\hline Application rate (kg COD/m ${ }^{3}$ r. d) & $6-10$ & $5-10$ \\
\hline Hydraulic detention time (h) & $6-18$ & $7-12$ \\
\hline Speed of liquid (m/h) & $0.5-1$ & 80 \\
\hline Speed of biogas (m/h) & $0.5-0.9$ & 90 \\
\hline COD removal efficiency sol. (\%) & 80 & \\
\hline BOD removal efficiency sol. (\%) & 90 & 2 \\
\hline
\end{tabular}

Source: DIAS e DE LAMO (n.d.).

80 and 146 US\$/toe, while for diesel, gasoline and alcohol, these costs were of 327,436 and 237 US $\$$ / toe respectively. SALOMON et al. (2008) report a cost of $0.013 \mathrm{US} \$ / \mathrm{Nm}^{3}$ when considering the external use of the byproduct as a fertilizer.

Recent technological developments in biodigesters must be considered, as is the case of the Internal Circulation Anaerobic Reactor - IC for its ingenuity and simplicity. This reactor consists of a vertical cylindrical tank with height from $16 \mathrm{~m}$ to $30 \mathrm{~m}$ and small surface area. Like the UASB, the byproduct enters from below and comes out the top of the reactor, however with two phase separators (gas-liquid). A comparison between the UASB and IC concepts may be made using the data of the Table 3.

According to the same source, the IC anaerobic reactor has the advantages of smaller susceptibility to organic overcharges, temperature shocks, toxic products, smaller soda consumption in function of the $\mathrm{pH}$ through internal recirculation, smaller occupied area and principally smaller implementation cost. In the same article it is mentioned that 70 reactors have been installed in Brazil and another 340 in the world, of which 21 in bio-ethanol industries.

It is fundamental that the new reactors have low implementation cost, are robust, operate in a way that tolerates possible variations in the load composition and have good economic viability in order to be adopted by the plants. It is also important to note that the energetic reality is very dynamic and that, from 1995 onwards, there has been great variation in prices of energy products in the international market. So, any analysis should consider historical series and, as far as possible, try to forecast future tendencies, both in international oil price as in the Brazilian industry itself. It is important to discuss once again the viability of vinasse bio-digestion, considering the price of diesel oil practiced internally, the energy and environmental advantages of using the methane gas from vinasse bio-digestion.

The energy value of biogas, combined to the pollution reduction by the anaerobic treatment, makes bio-digestion a process which deserves continuity in research and in application. This is particularly interesting for the sugar-ethanol sector which seeks to minimize environmental impacts, reduce the use of fossil fuels and sugar and ethanol production costs.

After bio-digestion the byproduct still has potassium, as well as a higher level of nitrogen, which means it has a high value as a fertilizer. This question should be considered as a positive externality when calculating the cost of biogas. 


\section{Vinasse Combustion or Incineration}

Direct combustion or incineration is a technology which allows almost complete disposal and definitive elimination of the polluting potential of vinasse. In spite of these advantages, there aren't records of recent experiences, especially related to sugarcane vinasse.

The idea of burning vinasse is possibly closely related to burning of black liquor, effluent in the paper production process (kraft method) (MERRIAM, 1982). In that process, the black liquor is incinerated or burned in recovery furnaces, as they recover salts present in the liquor. Hence, the incineration of the black liquor has the following purposes:

- elimination of the byproduct and, therefore, its polluting power;

- economical recovery of the salts;

- improvement of energy use.

With vinasse, the advantages would be the same, with the difference that the element to be recovered is basically potassium which a fundamental element in fertilization used in the production of sugarcane and its has high economic value and is the main economic justification of fertirrigation.. In this way, by burning or incinerating vinasse, the salts could be recovered and used as a fertilizer with the advantage of reduced transportation cost.

However, there are few experiments with sugarcane vinasse combustion. For example, in the technical literature works by NILSSON (1981), SPRUYTENBURG (1982) and CORTEZ and BROSSARD (1997). These works refer to concentrated vinasse, but without additives and also to the concentrated vinasse emulsions mixed to conventional liquid fuels, such as diesel oil and fuel oil. Athough vinasse incineration technology was presented as commercially viable by two companies in the early 1980s (ALFA LAVAL and HCG), currently there are still no commercial project in operation.

Thermal conversion of a fuel is connected to its nature and physical-chemical characteristics. With vinasse, the main problem in burning is related to the large quantity of water which makes it a product of very low calorific value and thus the first thing is to reduce its water level. The issue of vinasse concentration is discussed below.
However, what is debatable is to which point or which level of solids is it economically interesting to concentrate the vinasse. Burning tests already held, and shown below, considered that the vinasse, when showing a level of solids above $60 \%$, already has a sufficient calorific value to burn. This concentration sould be considered a "good compromise" between good fluidity (relatively low viscosity), still allowing reasonable atomization of the vinasse in conventional boilers; also that no large amount of energy is neded for its evaporation.

However, tests conducted by POLACK et al. (1981) and by CORTEZ and BROSSARD (1997) did not result in successful results, most probably due to the inadequate fuel for the burning method. To continue to use atomization as burning technique, it was chosen to work less concentrated vinasse (40\%) and mixed with fuel oil. This would ensure an even lower viscosity associated to a much higher calorific value of the mixture.

DEDINI commercializes the technology developed by Vogelbush for vinasse concentration (Figure 6), to operate fully integrated with the distillery.

\section{Methods for Vinasse Burning}

Among the known technologies for burning liquid fuels, atomization is, probably, the extensively used. However, atomization is not much used for fuels such as oils, which have a higher calorific value and practically only volatile carbons, making its combustion very easy. Atomization of vinasse represents a challenge, as its rheological characteristics change a considerably as concentration of solids increases, compromising therefore, a good atomization and consequent combustion.

There is also, however, burning technology using a fluidized bed reactor. This technology is employed in the burning of viscous products, such as remaining of liquid foods (e.g. soups), paste byproducts which show difficulty in breaking into small particles through atomization and also require, like vinasse, a very efficient thermal contact for burning.

GUPTA et al. (1968) were probably the pioneers in using the fluidized bed burning technology for sugarcane vinasse. The vinasse was prepared 


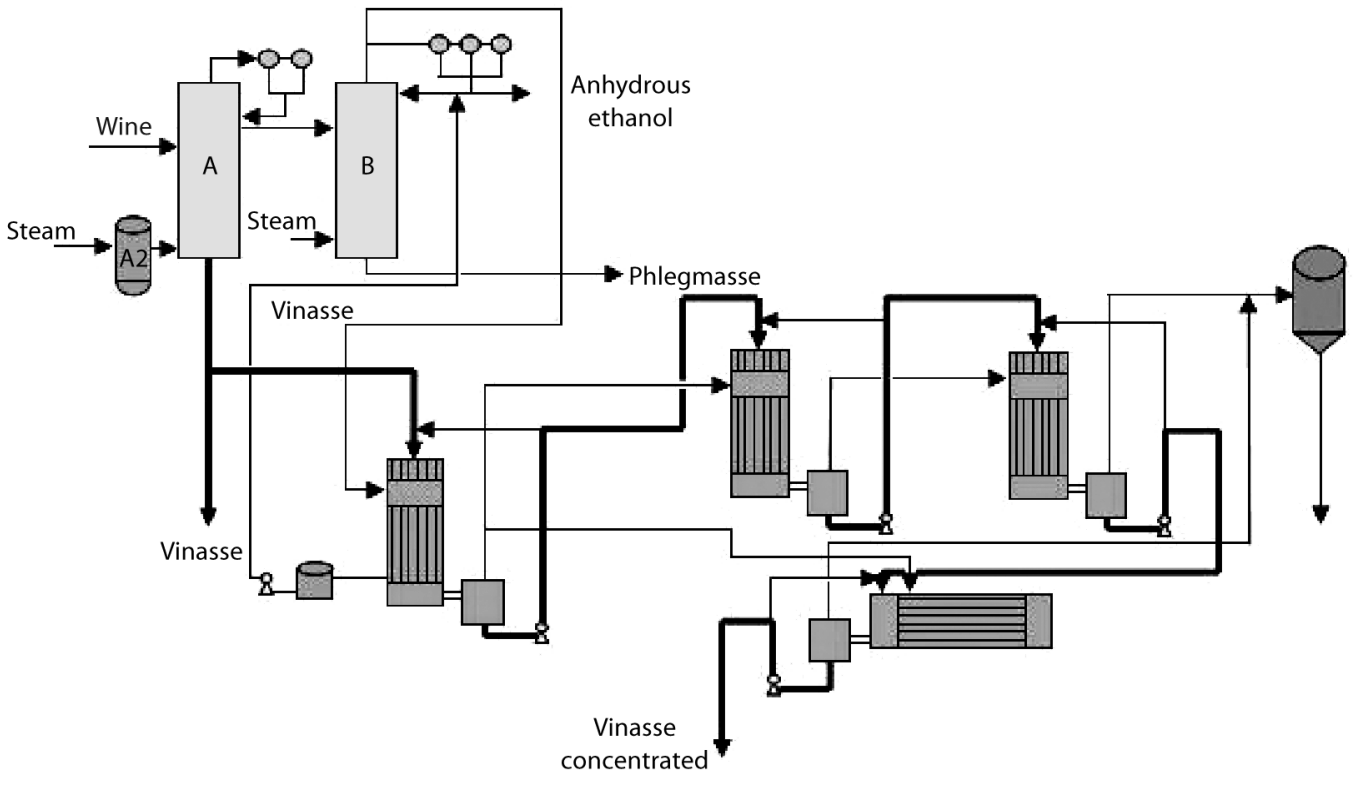

Source: OLIVÉRIO (2005).

FIGURE 6 DEDINI/Vogelbush process of vinasse concentration.

at 30 to $40{ }^{\circ}$ Brix and burned at $700{ }^{\circ} \mathrm{C}$. A similar process was described by DUBEY (1974) using vinasse and pulp burnt together.

WHEELER (1976) pointed out some advantages of the fluidized bed technology and estimated in a few million squared meters the heat transference are in a reactor with only $1 \mathrm{~m}$ diameter and particles with granulation smaller than $1 \mathrm{~mm}$. The same author stated that vinasse may be burned in this type of reactor with a level of solids between $30 \%$ and $35 \%$ without the use of auxiliary fuel. Finally the author proposes an incineration system for vinasse based on the fluidized bed technology. The system proposed was designated Copeland Fluidized Bed System. The installed cost of the unit was of US\$500,000 for about 22,000 liters of vinasse/day, producing 160 $\mathrm{kg}$ of ash/hour.

It is considered, however, that just as important or perhaps more than the burning method, are the fuel characteristics. The German company SAAKE is developing a burner for fluids with characteristics similar to vinasse, which it plans to sell in Brazil, where it is carrying out tests for this vinasse burning technology.

\section{Characteristics of Vinasse as a Fuel}

Among the most important properties for characterization of a fuel are the calorific value and the quantities and the proportion of fixed and volatile carbon. These characteristics may be evidenced when making elementary and immediate analysis of this fuel.

CORTEZ and BROSSARD (1997) presented values of the volatile carbon level for fresh and dry sugarcane vinasse, of $48.67 \%$ and $69.31 \%$ respectively. The vinasse in question was obtained from HTM - high test molasses, fermentation of the Shepherd Oil distillery in Mermentau, LA, USA. Even though these values do not represent average values for the Brazilian distilleries, they indicate that the samples had a good potential for its energy application through combustion/incineration.

The calorific power of vinasse strongly depends, as was expected, on the vinasse concentration. The values published by KUJALA (1979) were of $7,800 \mathrm{~kJ} / \mathrm{kg}$ for vinasse with $45^{\circ}$ Brix molasses. According to the same author, the value for completely dry vinasse has a calorific power of up to $14,390 \mathrm{~kJ} / \mathrm{kg}$. 
However, when dealing with mixtures or emulsions with fuel oil, the calorific power will depend not only of the level of solids in the vinasse, but also the proportion of vinasse to oil used.

Another important parameter in combustion is the adiabatic flame temperature of the fuel, also known as theoretical temperature of the flame. This parameter, strongly dependent of the fuel composition, was calculated by CORTEZ and BROSSARD (1997) for the vinasse obtained from the Shepherd Oil distillery. Using an air/fuel relation of $7.621 \mathrm{~kg}$ of air/kg of dry fuel without ashes, the values are of $700{ }^{\circ} \mathrm{C}$ for vinasse with $50 \%$ solids and $793{ }^{\circ} \mathrm{C}$ for vinasse with $60 \%$ solids.

\section{History of Vinasse Combustion}

The first tests found in the literature were published by KUJALA et al. (1976), of the Swedish company ALFA LAVAL. However, since World War I, the company Whitaker and US Industrial Chemicals Inc. developed the Porion furnaces. Next, REICH (1945) proposed a vinasse concentration in evaporators of quadruple effect up to a level of solids of $70 \%$ to $80 \%$ with subsequent combustion at $343{ }^{\circ} \mathrm{C}$ and recovery of the potassium in the ashes.

The same principle was used in Lucknow, in India, by CHAKRABARTY (1964) in the distillery Dyer Meaking Breweries Ltd. when a pilot plant was built to recover the potassium salts from the vinasse obtained in the alcohol production from molasses. In Brazil, it is known that two incineration plants were installed in Pernambuco more than 50 years ago, but were closed afterwards for economic reasons (D'ANDRADA, quoted by MONTEIRO, 1975).

The Dutch company NEM Bv states it has been researching vinasse combustion since 1947. According to the company, a special burner, a combustion chamber and atomization equipment have been developed and extensively tested in pilot plants. After many successful experiences on real scale, the concept was additionally improved and optimized. In 1986, the company introduced a new concept based on the installation of two boilers in the Bangyikhan distillery, in Bangkok, Thailand.
Each one of these installations had processing capacity of up to 6 ton/h of concentrated vinasse, while producing 15 ton/h of saturated vapor. Both incineration plants had satisfactory operation during 12 years.

The NEW Bv system consists in the following phases: preparation of vinasse (concentration), incineration, heat recovery, energy generation and ashes recovery. Vinasse with 10\% solids goes through an evaporator where it is concentrated to a $60 \%$ level. It is then pre-heated to $90{ }^{\circ} \mathrm{C}$ and, only then, follows to the incinerator.

In July 1981, the HCG company installed in Bangkok, Thailand, a sugarcane vinasse incineration plant. The distillery produced 90,000 liters of alcohol/day and 1,000 $\mathrm{m}^{3}$ of fresh vinasse/day. The vinasse was then evaporated in multiple effect Vogelbusch evaporators and burnt with $60 \%$ solids. The HCG company also claims to have installed a second incineration system at the same plant for a 180,000 liters of alcohol/day distillery.

The Swedish company ALFA LAVAL also published (NILSSON, 1981) results of a joint-venture with Finnish company A. Ahlström AB, specialist in combustion, which indicates the technical and economical viability of vinasse combustion. In the published works the use of the swirl combustion technology for burning of $60 \%$ solids vinasse is mentioned.

In spite of the referred texts indicating technical success in the experiences held, there is lack of information as to how they were conducted. This fact is verified also in the works published and contacts made by companies such as ALFA LAVAL and HCG. This lack of information hinders the adoption of the combustion technology which could be converted into an important alternative for vinasse disposal.

Another procedure tested to incinerate vinasse were the tests held between 1984 and 1987 in the Combustion Laboratory of the Mechanical Engineering Department of the Louisiana State University, in Baton Rouge, LA. USA.

The combustion experiments held varied the vinasse and fuel oil proportions. The proportions were used in a way to initially burn only fuel oil and, after that, increasing quantities of vinasse in 
the mixture, $(10 \%, 12.5 \%, 15 \%, 25 \%, 40 \%$ and $50 \%)$. However, more studies by combustion and salt recovery specialists are necessary, as well as a technological development in the same way as happened with black liquor burning in the paper industry.

\section{Vinasse Concentration}

In the State of São Paulo, the São Paulo State Environmental Agency - Cetesb implemented in 2005 the Normative P 4231, regulating the use of vinasse, limiting dosages that may be applied due to the cationic exchange capacity - CEC and the levels of potassium $(\mathrm{K})$ in the soil. There are already deadlines for the canals and reservoirs to be made impermeable. In the soil, if the K saturation in the CTC is greater than $5 \%$, the norm allows only the use of the dose which shall be consumed by the sugarcane in the year in question.

With this regulation on vinasse use, many areas will suffer restrictions, and the sector is already preparing to transport the vinasse to longer distances. One of the solutions being studied is vinasse concentration.

Vinasse concentration is made by removing water. The most conventional or well known way is evaporation by adding heat. However, there are other processes which may be used, but which still need research and development to adapt them to the system, making them more viable, both from the economic as the technical point of view.

Reverse osmosis consists in applying in the more concentrated solution a mechanical pressure that is greater than the osmotic pressure, obliging the solvent to go the inverse way. This technique could be applied to the vinasse concentration. However, the cost of this treatment is considered high.

Usina Santa Elisa, in São Paulo, installed back in 1978, a vinasse concentrating unit, acquired from the company Vogelbusch, which was hardly used due to the high energy cost. With the implementation of an electric energy co-generation system, in 1999, the vinasse concentrator started working, producing in the 2005/2006 harvest about $3.3 \mathrm{~m}^{3}$ of concentrated vinasse per hour.

The high energy cost of vinasse concentration is perhaps its main restriction. However, the evaporated water may be recovered for industrial re-use, reducing the need for fresh water. This condensate may go back to dilute the honey in fermentation, soaking the sugar mill, and other purposes depending on the biological treatment used. Not to mention the superior quality of this water in comparison to water taken from reivers, which would bring improvements to the process.

Usina Mundial, in Mirandópolis, SP, studies this technology. The joint project with company Agrif, aims to transform $80 \%$ of the liquid part of vinasse into distilled water, reducing water treatment costs and promoting re-use of a natural resource. In addition, it also plans producing a pelletized or granulated potassium fertilizer, with the remaining solid part.

DEDINI recently announced projects of selfsufficient mills in water consumption and also in water producing units (ÁGUA, 2009). Reduction in water consumption in the mills is an old concern, as it is an important natural resource of limited supply. By adopting the vinasse concentration by evaporation system, it would be possible to recover the cane water and transform the sugarcane mill from consumer to exporter of water. This is possible, since sugarcane is 70\% water in its composition. So, water may be yet another product obtained from sugarcane.

Water evaporation by adding heat must consider, in the mill's balance calculations, the availability of vapor in the correct pressure and temperature for such. As well as the need for a system to condensate the evaporated water.

Using cooling evaporating towers for vinasse water evaporation may be an option. However, the efficiency of this method must be considered in relation to the psychrometric conditions of the air. Like evaporation by heating, a cooling system to recover the evaporated water must be considered. In this case, due to the vapor condition of the water, condensation requires cooling to temperatures below dew point in the air, where a refrigeration system would be necessary.

According to PENATTI (2007) and FINGUERUT quoted by PENATTI (2007), vinasse evaporation difficulty is both due to its corrosiveness and incrusting tendencies (due to the presence of salts) 
as for the difficulty in thermal balance, that is, availability of vapor with adequate pressure and places to integrate the low-pressure vapors or water (cold currents) to condensate them.

\section{FINAL CONSIDERATIONS}

There are many methods which may be used to help solve the vinasse issue. There is no telling which one is best, as this depends on each case and what really needs to be achieved. Whether it is only to reduce the volume or also produce energy or, even, to produce water. All of these aspects are important and, therefore, must be contemplated. Many of these methods may even be applied simultaneously, for example a part of the vinasse could be bio-digested and another concentrated or incinerated. There is the possibility for energy integration of these processes, a question which should be considered further.

However, there are different points of view in respect to each technology, with each idea claiming to be the best option. The trend in R\&D is that there is an urgent need to develop an in situ disposal technology for vinasse. It is true that there are advantages to fertirrigation for recycling or economy of fertilizers, but this technique will hardly be totally accepted in other countries or even possible in different places of Brazil which have other soils and other agronomical responses.

\section{REFERENCES}

ÁGUA. Gerenciamento adequado de água nas usinas sucroalcooleiras permite economia dos recursos minerais e energéticos e até renda extra. Revista Água, edição 9. Disponível em: <http://www.h2oagua.com.br/edicao09_sucro.asp>. Acesso em: 5.02.2009.

AMORIM, H. V. Fermentação alcoólica: ciência e tecnologia. Piracicaba, SP: Fermentec, 2005, 448 p.: il.

AMORIM, H. V. Fermentação alcoólica. Disponível em: $<$ http://www.stab.org.br/agenda/eventos/8_cba/pales tra/henrique_fermentec_palestra.pps $>$. Acesso em: 25.07.2008.

ANDRADE, R. R. Procedimento para o desenvolvimento de um modelo matemático para o processo de fermentação alcoólica. 2007. 110 f. Dissertação
All things considered, the need for investment in research and development in this area is eminent, in order to develop and improve processes and, also, to eliminate certain preconceptions, considering that the environmental pressure will remain strong.

The following themes are suggested for future research:

- cooling the fermentation recipients, with integration to the processes at the distilleries;

- vinasse combustion (in situ disposal): concentration technology, mixture to other fuels such as pulp and biogas;

- removing the potassium from bio-digestion byproduct;

- energy integration of concentration with distillation and cogeneration;

- production of protein for animal food from vinasse;

- bio-digestion as a source of energy to dry yeast;

- definition of the relation between vinasse recirculation rate and energetic performance of concentration/combustion;

- application of the analysis of the life cycle as a comparison tool of different options for vinasse treatment and disposal;

- determining the cost of biogas, including externalities related to avoided fertilization and its use as fuel to dry yeast.

(Mestrado em Engenharia Química) - Faculdade de Engenharia Química, Universidade Estadual de Campinas. Campinas, SP. 2007.

ATALA, D. I. P. Montagem, instrumentação, controle e desenvolvimento experimental de um processo fermentativo de produção de etanol. 2004. 172 f. Tese (Doutor em Engenharia de Alimentos) - Faculdade de Engenharia de Alimentos, Universidade Estadual de Campinas. Campinas, SP. 2004.

ASHRAE. ASHRAE Fundamentals Handbook, (cap. 17, p. 17.6), Atlanta; American Society of Heating, Refrigerating and Air-Conditioning Engineers, Inc., 1997.

BHANDARI, H. C.; MITRA, A. K.; MALIK, V. K. Treatment of Distillery Effluent. In: XLIII Annual Convention of 
the Sugar Technologists Association of India, Proceedings... Kanpur, Índia, p. G65-G72, 1979.

CHAKRABARTY, R. N. Potash Recovery - A Method of Disposal of Distillery Wastes and Saving Foreign Exchange. In: Symposium on Ethyl Alcohol Production Technique, New Delhi, Índia, p. 93-97, Publ. Noyes Development Corp., N.Y., U.S.A., 1964.

CODISTIL/DEDINI. Biostil: um novo conceito na produção de álcool. Catálogo CODISTIL/DEDINI, 1983.

CORTEZ, L. A. B.; BROSSARD PEREZ, L. E. Experiences on Vinasse Disposal - Part III: Combustion of Vinasse-\#6 Fuel Oil Emulsions, Brazilian Journal of Chemical Engineering, 14(1)9-18, 1997.

CRAVEIRO, A. M.; SCHMIDELL NETTO, W.; VILLEN, R. A.; HIRATA, Y. S. Anaerobic Digestion of Stillage at Low Retention Time-Energy and Treatment Efficiencies. In: V International Alcohol Fuel Technology Symposium, Auckland, New Zealand, 13-18 maio, 6p., 1986.

DIAS, C. A. B. Análise preliminar da possibilidade de utilização do vinhoto como recurso energético, Brasil Açucareiro, 97(6):29-37, 1981.

DIAS, N.; DE LAMO, P. Reatores anaeróbios de leito expandido para o tratamento de vinhaça das indústrias de bioetanol. Artigo técnico IC Vinhaça-Bioetanol Dedini e Paques, [19-].

DUBEY, R. S. Distillery Effluents-Treatment and Disposal, Sugar News Ann, número 6, p. 9-26, 1974.

FINGUERUT, J.; MEIRELLES, A. J. A.; GUIRARDELLO, R.; COSTA, A. C. Fermentação, hidrólise e destilação. In: CORTEZ, L. A. B.; LORA, E. S.; OLIVAREZ GÓMEZ, E. Biomassa para energia. Editora da Unicamp. Campinas, SP. 2008. Cap. 13, p. 435 a 473.

GONÇALVES, D. B. Os impactos no meio ambiente. In: VIII WORKSHOP IMPACTOS NA EVOLUÇÃO DO SETOR. Apta - Coordenadoria de Assistência Técnica Integral. 15 maio 2008, Campinas-SP. Position Paper disponível em: <http://www.apta.sp.gov.br/cana/anexos/position_ paper_painel3_daniel.pdf>. Acesso em: 25.07.2008.

GUPTA, S. C.; SHULA, J. P.; SHULA, N. P. Recovery of Crude Potassium Salts from Spent Wash of Molasses Distilleries by Fluidized Incineration, 1968. In: XXXVI Annual Conv. Sugar Technology Ass., Proceedings.. Índia, XXXXIII-1 a XXXXIII-7, 1968.

GUTIERREZ, L. E. Produção de álcoois superiores por linhagens de Saccharomyces durante a fermentação alcoólica. Sci. agric. Piracicaba, 50(3): 464-472, out./ dez. 1993. Disponível em: <http:/www.scielo.br/pdf/sa/ v50n3/21.pdf>. Acesso em: 22.07.2008.

KUJALA, P. Distillery Fuel Savings by Efficient Molasses Processing and Stillage Utilization, Sugar y Azucar, out., p. 13-16, 1979.
KUJALA, P.; HULL, R.; ENGSTROM, F.; JACKMAN, E. Alcohol from Molasses as a Posssible Fuel and the Economics of Distillery Effluent Treatment, Sugar y Azucar, mar., v. 71, p. 28-39, 1976.

JORDAN, R. A. Desenvolvimento de uma bomba de calor água-água acionada a biogás para utilização em processos de aquecimento e resfriamento em laticínios visando a racionalização do uso de energia no nivel de produção leiteira. 2005. Tese (Doutorado) - Faculdade de Engenharia Agrícola, Unicamp, 2005.

LUCAS JR. J. de; SILVA, F. M. Biogás: produção e utilização. FCA-Unesp, Jaboticabal, SP, 1990.

LUCAS JR., J. de; CORTEZ, L. A. B.; SILVA, A. Biodigestão. Capítulo X. In: CORTEZ, L. A. B.; SILVA-LORA, E. (Coord.) Tecnologias de conversão energética de biomassa. Série Sistemas energéticos II, Manaus, AM, Editora Universidade do Amazonas, 527 p., 1997.

MERRIAM, R. L. Simulation Analysis of Liquor-firing and Combustion Processess in Kraft Recovery Furnaces, Tappi Journal, p. 112-116, set. 1982.

MONTEIRO, C. E. Brazilian Experience with the Disposal of Waste Water from the Cane Sugar and Alcohol Industry, Process Biochemistry, nov., p. 33-41, 1975.

NILSSON, M. Energy Recovery from Distillery Wastes, from Alfa Laval A.B., International Sugar Journal, set., v. 83, ed. 993, p. 259-261, 1981.

OLIVA NETO, P. Efeito de fatores inibidores na fermentação alcoólica. In: XVI Workshop Produção de Etanol: qualidade da matéria-prima. 30 maio 2008. Escola de Engenharia de Lorena - EEL, USP, Lorena-SP. Position Paper disponível em: <http://www.apta.sp.gov.br/ cana/anexos/position_paper_painel3_pedro_oliva.pdf $>$. Acesso em: 22.07.2008.

OLIVÉRIO, J. L. Concentração de vinhaça, tecnologias, equipamentos e sua integração energética numa destilaria. In: Simpósio Internacional e Mostra de Tecnologia da Agroindústria Sucroalcooleira, 2005.

PARAZZI, C. Fatores físicos e químicos que influenciam a fermentação alcoólica. Disponível em: <http://www. cca.ufscar.br/ vico/Fatores\%20fisicos\%20e\%20quimicos\%20que\%20influenciam\%20a\%20fermentacao.pdf>. Acesso em: 22.07.2008.

PENATTI, C. P. Vinhaça e seus efeitos no solo e na planta. In: Workshop Tecnológico sobre Vinhaça. 10 out. 2007. FACV/Unesp - Campus de Jaboticabal. Position paper disponível em: <http://www.apta.sp.gov.br/cana/anexos/ Position_Paper_sessao3_claudimir.pdf $>$. Acesso em: 04.02.2009.

PINTO, C. P. Tecnologia de biodigestão anaeróbia de vinhaça e desenvolvimento sustentável. Tese (Mestrado) - Faculdade de Engenharia Mecânica, Unicamp, 1999. 
POLACK, J. A.; DAY, D. F.; CHO, Y. K. Gasohol from Sugarcane-Stillage Disposition. Audubon Sugar Institute, Louisiana State University, September, p. 47, (1981).

REICH, G. T. Production of Carbon and Potash from Molasses Distillers' Stillage. Trans. Amer. Inst. Chem. Engrs. , 41, p. 233-251 (1945).

ROCHA, M. H.; LORA, E. E. S.; VENTURINI, O. J. Life Cycle Analysis of Different Alternatives for the Treatment and Disposal of Ethanol Vinasse. Sugar Industry/ Zuckerindustrie, Berlin, Germany, v. 133, p. 88-93, 2008. SALOMÓN, Karina Ribeiro; LORA, Electo Eduardo Silva. About the real cost calculation for biogas from ethanol stillage biodigestion and its energy utilization. In: XVI Europeian Biomass Conference. Proceedings... Valencia, Spain. ETA Florence Renewable Energy, 2008. p. 1644-1650.

SILVEIRA, A. M. In: SOPRAL op.cit. p. 29-44.
SOUZA, M. E.; FUZARO, G.; FURCO, A. M. Biodigestão termofilica de vinhaça. Proceedings of STAB (Sociedade de Técnicos Açucareiros e Alcooleiros do Brasil) Congress, Águas de São Pedro, SP, August, pp. 205-211 (1993).

SOUZA, E. M.; PAULA JR., D. R. Análise técnico-econômica da biodigestão anaeróbia da vinhaça de cana-de-açúcar para fins energéticos. In: Congresso Brasileiro de Energia - CBE, vol. 3, p. 1339-1344, Anais... Rio de Janeiro, RJ, (1999).

SPRUYTENBURG, G. P. Vinasse Polution Elimination and Energy Recovery, from Hollandse Constructie Groep B.V., International Sugar Journal, March, p. 73-74 (1982).

WHEELER, C. M. The Incineration of Stillage in FluidizedBed Systems. In: Seminário Internacional sobre Tratamento de Vinhoto - Rio de Janeiro, Anais... ago. 1976, p. 4-61/4-69. 